\title{
Eğitim Araştırmalarında Kuramın Ölümü ${ }^{1}$
}

\section{David Geelan}

Alberta Üniversitesi

\section{Çevirenler}

Mukaddes Erdem, Hacettepe Üniversitesi, ORCID ID: 0000-0002-8724-3923

Tuğba Öztürk, Ankara Üniversitesi, ORCID ID: 0000-0000-3377-7012

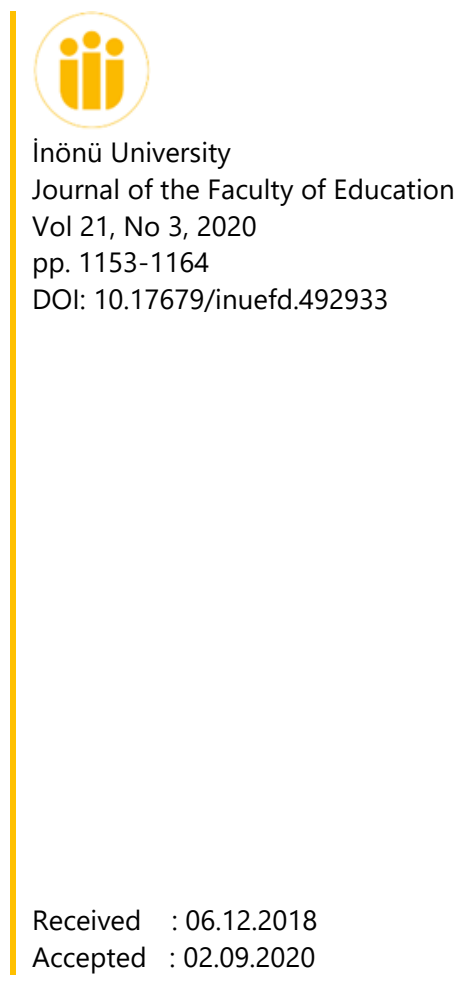

Önerilen Atıf

Geelan, D. (2020). Eğitim Araştırmalarında Kuramın Ölümü (Çev. M. Erdem \& T. Öztürk). Inönü Üniversitesi Eğitim Fakültesi Dergisi. Vol 21, No 3, 2020 pp. 1153-1164, DOI: 10.17679/inuefd.492933 (Geelan, 2003).

\footnotetext{
${ }^{1}$ Geelan, D. (2003). The Death of Theory in Educational Research. In B. Davis (Ed.), Proceedings of the first Conference on Complexity Science and Educational Research (pp. 169-185). Edmonton: University of Alberta.
} 


\section{GíRiş}

Birkaç yıl önce şöyle yazmıştım:

Doğa bilimlerinin - özellikle fizik, biyoloji ve jeoloji gibi- teknolojik ve sosyal alanlardaki başarısı 19 . ve 20 . yüzyıllarda enteresan bir sonuca yol açmıştır: Doğa bilimlerinin söylem biçimleri ve felsefi bakış açıları diğer söylem ve yaşam biçimlerine genişletilmiştir. Bunun en güçlü örneği; akademik psikolojinin modernist programla ve fizik bilimler üzerine modellenmiş, son derece genel, neden sonuç ilkeleriyle uzun süren bağlılık ilişkisi (Polkinghorne, 1992) ise de; bilim felsefesinden doğan bakış açıları, eğitim araştırması alanyazını için de güçlü ve kalıcı referans noktaları olmuştur. (Geelan, 2001b).

Eğitim araştırmalarının, paradigma olarak, fizik bilimlerinin yöntemleriyle sürdürdüğü uzun süren bağlılık ilişkisi bir düş kırıklığı ile sona ermektedir. Son 20 yılı aşkın bir süredir, nitel araştırmaya yöneliş, eğitim araştırmalarını, bir uzmanlık alanı olmaktan çıkarıp, Habermas'ın (1971) terimleriyle, 'teknik' ilgiden "pratik" insan ilgisine doğru yöneltmektedir. Denzin ve Lincoln (1994, 2000' nün, diğerlerinin yanı sıra, eğitim araştırmalarına özgürleştirici ilginin özelliklerini katmaya dönük çabalarından da söz edilmelidir. Ancak benim iddiam, bu yöntemlerin hala tatmin edici sonuçlar vermeyeceği yönündedir. Çünkü Onlar, bilginin araştırmacılar tarafından üretildiği ve uygulayıcılar tarafından uygulandığı (niyet bu olsa da gerçekte her zaman böyle olmamaktadır) anlayışına temellenen bilimsel araştırma paradigmasına sıkışıp kalmışlardır. Sonuçta ortaya çıkan, "kuram-uygulama boşluğu"nun işaret ettiği gibi; ki ben burada bunu tartışacağım, eğitim kuramlarının eğitim uygulamalarını iyileştirmede büyük ölçüde etkisiz kalmasıdır. Kapsamlı 'reform' hareketleri sıklıkla, eğitim araştırmalarından çok ideoloji üzerine temellenmektedir, zira araştırma, uygulama üzerinde etkili görülmemektedir.

Bu kuram ve uygulama boşluğu için birçok mantıklı açıklama bulunmaktadır ve sorumluluk, birçok duruma paylaştırılmaktadır. Ancak ben inanıyorum ki bu, temelde problemin yanlış anlaşılmasından kaynaklanmaktadır. Sınıfların, insan çevreleri olarak karmaşıklığı onları, kuram-uygulama ikilemini sürdüren yaklaşımlara mahkum etmektedir. Oysa eğitim araştırmaları için uygun modeller, fizik bilimlerden ziyade, mühendislik ve malzeme bilimlerinden türetilebilir. Uygulamaya dair genellenebilir bilgi yerine, uygulamada çalışan, güçlü, bağlama-duyarlı çözümler arayışı bu araştırma alanlarının temel amacıdır. Eğitim araştırmalarında bir model olarak "teknolojik problem çözme", önemli işlevsel yararlar sağlayabilir. Eğitim uygulamalarını anlamayı ve bizzat eğitimciler kanalıyla bu uygulamaları sınıflarda yaşatmayı olanaklı kılan çift yönlü projeler üretmeyi sağlayabilir.

Birçok açıdan karmaşıklık bilimi bana, kendini açıkça tanımlamış görünüyor: sınırları olan, sabit bir tanım yaratarak değilse de; belirli örnekleri -sinirsel ağlar, hücresel otomasyon, genetik algoritmalar vb.- işaret ederek ve "bu karmaşık bir sistemdir" diyerek. Amacım doğrultusunda burada 'karmaşıklığı', incelenen şeylerin indirgenemez niteliği açısından tanımlayacağım:

Karmaşık sistemler indirgeyici analizlere tabi olmayan sistemler olarak tanımlanacak. Karmaşıklık (complexity), bu anlamda, karışıklık (complication) ile eşanlamlı değildir: Bir sistem karışık olabilir fakat bileşenlerine indirgenerek basitleştirilebiliyorsa (ele alınabiliyorsa), bu tanıma göre, karmaşık bir sistem olarak düşünülemez.

Böyle bir tanımın oluşturacağı temel zorluk, karmaşıklık ilkesi uyarınca belirli bir durumun karmaşıklığına karar vermenin güçlüğü ya da çok karışık bir sistemin sadece mevcut bilgi ve araçlarımızın sınırlıı̆̆ı nedeniyle karmaşık gibi görünüyor olması ihtimalidir. Ancak sistemlerin ilkesel olarak karmaşık (yani, daha basit bileşenlerine indirgenerek açıklanamayacak) olması ya da sadece şu anki bilgi birikimimizle analiz edilemeyecek karmaşıklıkta olması çok da önemli değildir. Eğer, ilahi güçlere sahip olsaydık, buna karar verebilirdik ancak ilerlemek için bu kararı vermeye ihtiyacımız yok. Eğer bir sistem, onu indirgeyerek ele alamayacağımız ölçüde karışıksa, başka bir yolla çözülmesi mümkün olmayan dirençli problemlerin çözümünde karmaşıklık biliminin araçları ve yaklaşımları işe yarayabilir.

\section{Bireysel Karmaşıklık}

Her bir öğretmenin ve öğrenenin sınıftaki düşüncelerini ve davranışlarını düşünelim: Bir yandan insan eyleminin/bilişinin (giderek tartışmalı olsa da bu ayırım bazen kullanışııdır) ilkesel olarak daha basit bileşenlerine indirgenemeyeceği ve bu nedenle karmaşık bir sistem olduğu düşüncesinin güçlü bir sezgisel çekiciliği var. Diğer yandan, yeterli yaşam boyu gözlem içeren ve bireyin kavrayışını, indirgemeci bir yolla dönüştüren yeterli işlem gücüne sahip bir deney tasarlamak da olanaklı olabilir. (Ancak) her iki görüşü de 
doğrulayacak yeterli kanıtımız yok. (Bu durumda) öğretmenlere ve öğrencilere karmaşık bireylermiş gibi - ya da en azından sınıfta yaptıkları, söyledikleri ve düşündükleri şeyler karmaşıkmış gibi- yaklaşılmasında kesinlikle yarar vardır.

Biggiero (2001) da, insan sistemlerinin karmaşık sistem olma özelliklerini taşıdığı görüşündedir.

\begin{abstract}
İnsan sistemleri, üç karmaşıklık kategorisine ait bazı karmaşıklık kaynaklarından etkilenir. Azalan kısıtlayııııık sırasıyla, birinci kategoriye ait sistemler kesinlikle öngörülemezler. Ikinci kategoriye ait olanlar sonsuz bir hesaplama kapasiteyle (belki) öngörülebilirler ve üçüncü kategoridekiler ise karmaşık bir hesaplama kapasitesiyle öngörülebilirler. Birinci karmaşıklık kategorisinin iki kaynağı vardır: doğrudan öz-referans (öznel anlam) ve Gödel'in eksiklik teoreminden doğan mantıksal karmaşıklık ile sosyal sistemlerde oluşan ve bir tür belirlenemezlik ilkesiyle sonuçlanan ilişkisel karmaşıklık. İkinci kategorinin üç karmaşıklık kaynağı vardır: olası farklı algılardan oluşan bilgikuramsal (gnosiolocial) karmaşıkık; işaretler ve olguların sonsuz olası yorumunu temsil eden göstergebilimsel karmaşıklık; ve doğrusal olmayan dinamik sistemlerdeki olayları karakterize eden kaotik karmaşıklık. Üçüncü kategori ise esasında matematikte çözülemezlik (intractability) anlamına gelen hesaplama karmaşıklığına karşılık gelir. Yapay, doğal, biyolojik ve insan sistemleri farklı karmaşıklık kaynaklarının etkisi ile karakterize edilmektedir ve en sonuncusu (insan sistemleri) en karmaşık olarak görünmektedir (s. 3).
\end{abstract}

Yani Biggiero, saydığı tüm (altı) karmaşıklık biçimleri açısından, insan sistemlerinin yüz yüze olduğumuz en karmaşık sistemler olduğu görüşündedir.

\title{
Sınıfın Karmaşıklığı
}

Her bireyin karmaşıklığının ötesinde, elbette, bir sosyal ortam olarak sınıfın karmaşıklığı da bulunmaktadır. $\mathrm{Bu}$, öncelikle 20-40 kişi arasındaki olası etkileşimlerin ve ilişkilerin iki-boyutlu bir karmaşasından oluşmaktadır ki; eğer bir sınıfı, odadaki her bir kişiyi bir diğer kişiyle birleştiren tek, basit bir çizgi şeklindeki bir şema olarak hayal edersek, zaten bu görüntü, bağlantılardan ve etkileşimlerden oluşan çok karmaşık bir örümcek-ağı görünümü oluşturacaktır. Bu görünümde, bazı ipler diğerlerinden daha güçlü ve yapısal olarak daha önemli olacak ve görünüm sürekli bir değişim içinde bulunacaktır.

Bu karışıklığa yeterince dikkat edememem nedeniyle ortaya çıkan bir zorlayıcı öğretim deneyimimi tartışırken şöyle yazmıştım:

\footnotetext{
Derste ortaya çıkan çatısmalar...ortaya çıktılar çünkü, büyük ölçüde öğrenciler, benim rolümü doğru biçimde yerine getirmede başarısız olduğum algısına sahiptiler. Dersteki eylemlerim ve epistemolojik yükümlülüklerim, onlar için "eğitimcinin rolünü" tanımlayan beklentiler dizisine aykırıydı. Başka bir deyişle... sınıftaki sosyal yapıları ve etkileşimleri tek tarafı olarak değiştirmeye çalışmıştım ve öğrenci beklentileri ağı tarafından "pozisyonuma geri çekilmiştim".
}

\begin{abstract}
Yukarıdaki ağ metaforunu biraz daha ileriye götürebiliriz. Bahçemdeki bir örümceğin ağını; öğlen civarı, ağın merkezinde, güneşin altında oturmasını olanaklı kılacak şekilde ördüğünü düşünelim. Mevsim ilkbahardan yaz aylarına doğru değiştiğinde, güneş (Avustralya'da) daha güneye hareket eder ve örümceğin ördüğü ağın ilk pozisyonu güneşi doğru zamanda yakalayamaz. Ve örümcek ağ üzerinde farklı bir noktaya hareket ederse ${ }^{2}$ artık bu pozisyon ağın merkezi değildir. Bu durum; ağın kenarlarının daha az kuvvetli olması, örümceğin ağırlığını kaldıramaması ve bir sinek ağa takıldığında, ona haber veren ayağıyla tuttuğu ağların kendisinden çok uzakta olmasını saymazsak, arzu edilir görünebilir... (Zira) ağın merkezinin değiştirilmesi için, tüm ağın zahmetli bir şekilde yeniden örülmesi gerekecektir. Benzer şekilde, benim de 'merkezden uzaklaşmam', beklentiler ağını zedeledi ve işlevsiz hale getirdi. İşlevsel bir hareket olarak, grupla işbirliği içinde ağı yeni baştan örmem gerekirdi. (Geelan, 2001a).
\end{abstract}

Örümcek ağı ile imgelenen yapı, basit etkileşimlerden ve ilişkilerden çok beklentilerden ve inançlardan oluşmaktadır. Böylece bir anlamda, sınıf üyeleri arasındaki muhtemel bağlantılar ağına bir karmaşıklık katmanı eklenmektedir. Katılımcıların beklentilerini eklediğimizde, üçüncü bir uzamsal boyuta geçerek (yapıyı), 2 boyutlu bir ilişkiler ağı (1 boyutlu bireysel karmaşıklık ağı üzerine konumlandırılmış) olarak hayal edebiliriz.

\footnotetext{
2 ÇN: güneş ışığını yakalamak için
} 
Çoğu eğitimci, sınıfların karışık yerler olduğu yönündeki önermeleri kabul etse de ben, bu karışıklığın başka boyutlarının da olduğu iddiasındayım- sadece çok sayıda paydaşın ve onların etkileşimlerinin getirdiği değil, aynı zamanda bu tür etkileşimlerin altında yatan inançların ve varsayımların karmaşıklığı da... Başka bir deyişle, çoğu eğitimci okulların, Jurgen Habermas'ın (1971) terimleriyle "teknik" karışıklıklarının farkındadırders saati baskıları, azalan bütçeler, artan sınıf mevcutları ve devletin, ebeveynlerin ve işveren kurumların rekabetçi talepleri... Ben daha çok, "pratik" ve "özgürleştirici" karışıklıkla ve okulların, zengin iletişimsel ilişkilerin gelişimini kısıtlayıcı, yarışmacı varsayımlar ve inançlardan gelen karmaşıklığı ile ilgileniyorum:

Mezirow (1981), Habermas'ın fikirlerini tanımlamak, yorumlamak ve eğitsel bağlamda uygulamak için şöyle bir açıklamaya başvurur:

\begin{abstract}
Habermas, insan ilgisinin ürettiği bilginin (knowledge) üç genel alanını birbirinden ayırır. Bu alanlar "bilgi olușturucudur (knowledge constitutive)", çünkü bilgi olarak yorumladığımız şeylerle ilişkili kategorileri belirlerler. Ayrıca bu alanlar, bilgi keşfetme yöntemini (mode) ve üretilen bilginin geçerli temellerinin olup olmadığını belirlerler. Habermas, üç temel bilişsel ilgisi- teknik, pratik, özgürleştirici- üzerinden, üç ayrı ama birbiriyle ilişkili öğrenme alanı önermiştir (Mezirow, 1981, s. 143-144)
\end{abstract}

Mezirow, teknik yöntemi 'çalışmaya' yönelik insan ilgisi ile, pratiği 'etkileşim' ile ve özgürleştirici olanı ise 'güç' ile ilişkili olarak tanımlamaktadır. Teknik yöntem "deneysel bilgiye dayalıdır ve teknik kurallara tabidir" (Mezirow, 1981, s. 144). Bu yöntem, doğa bilimlerinde kullanılan ve aynı zamanda öğretimdeki "süreç-ürün" (Shulman, 1986) araştırmalarının çoğunun dayandığı yöntemdir. Genel kurallarla açıklanabilen veya tanımlanabilen, öngörülebilir, gözlemlenebilir olaylarla ilgilidir. Bu kurallar doğru uygulanan nicel deneylerle ortaya konabilir ve benzer durumlara genellenebilir.

\begin{abstract}
Pratik yöntem, uzlaşılmış anlayış ve eylem normları üzerine inşa olan iletişim ve insan ilişkileri ile ilgilidir. Bu anlayış ve sorgulama tarzının amacı, teknik kontrol ve yönlendirme değil, iletişim ve öznelerarasılık koşullarının açıklığa kavușturulmasıdır. Bu göreve uygun olan yöntem, ampirik-analitik bilimlerin yöntemleri değil, nedensellik oluşturmaktan ziyade anlamın anlaşılmasını araştıran sistematik sorgulamadır. (Mezirow, 1981, s. 144)
\end{abstract}

Dolayısıyla pratik eylemler, insan iletişimi ve anlayışını geliştirirler ve ortak anlamların daha iyi bir şekilde inşa edilmesine olanak sağlarlar. Öğretimle ilgili araştırmalarda nitel/yorumlama (interpretive) geleneği, insanların (hem öğretmenlerin hem de öğrencilerin) nesnel teknik yaklaşımla araştırılmaları için gerekli öngörülebilirlik koşullarına tabi olmadıkları varsayımı üzerine kurulmuştur ve bu nedenle, (öğretim araştırmaları) öznelerarası pratik yöntemlerle yürütülmelidirler.

Özgürleştirici eylemler; kişinin özbilgisini, yaşadığı deneyimin etkileri üzerindeki yansıtmalarını ve güç yapılarının adaletsizliklerden özgürleştirici bir bakışla sorunsallaştırmasını içermektedir. Bu yaklaşım, ideolojilerin eleştirilmesi yoluyla insanın güçlendirilmesi ile ilgilidir. Eğer 'pratik' karışıklık boyutunun dahil edilmesi örümcek-ağı yapısını 2-D'den 3-D'ye genişletiyorsa, özgürleştirici alanı eklemek, 4 uzamsal boyutun geometrisine geçişi gerektirir! Ve bu 4 boyutlu ağa, tarihsel olarak konumlandırılmış olmasıyla ve zamana bağlı sürekli değişmesiyle beşinci boyut eklenmektedir.

Okulların ve sınıfların teknik, pratik ve özgürleştirici (bazen 'eleştirel' olarak da adlandırılır) düzeydeki karışıklığını (complication) görmemiz ile birlikte bu sistemlerin, öğrencilere hakkıyla destek hizmeti sunulması için basitleştirilemeyecek, indirgenemeyecek kadar karışık (complicated) sistemler olduğunu anlamaya başlarız. Bu sistemler bir şekilde son biçimini almış (ilkesel olarak karmaşık (complex)) sistemler olmasalar bile, bu aşamada bizim mevcut indirgemeci analiz etme becerimizin ötesinde sistemlerdir. Dolayısıyla, ancak karmaşıklık (complexity) biliminin araçları kullanılarak araştırılabilirler.

(Geleneksel) doğa bilimlerindeki modellerin, eğitim araştırmalarında bize iyi hizmet etmediğini ve etme gücüne de sahip olamayacağını ileri sürdükten sonra, bu modelleri ayrıntılı olarak ele almayı ve bu iddiayı araştırmak adına biraz daha zaman harcamayı istiyorum.

\title{
Bilim Felsefesinden Modeller
}

Alan Chalmers, Sir Karl Popper'in bilimin doğasına yönelik "yanlışlanabilirci" (falsificationist) bakış açısını şöyle açıklamaktadır:

Kuramlar, daha önceden ortaya atılan kuramlarda karşılaşılan problemlerin üstesinden gelmek ve dünyada ya da evrende bazı davranış biçimlerini yeterli bir şekilde açıklamak amacıyla, insan aklının özgürce yarattığı spekülatif ve geçici varsayımlar veya tahminler olarak değerlendirilir. Bir kez önerildiğinde, spekülatif kuramlar 
Popper'ın bakış açısı mantıksal pozitivizmin bir adım ötesindedir: Bilimsel kuramların doğru olduğunu iddia etmemekte; basit bir şekilde, en iyi kuramların, (a) gözlemleri, birbiriyle çelişen kuramlardan daha iyi açıklayan ve (b) henüz yanlışlanmamış kuramlar olduğunu belirtmektedir.

Bu bakış açısının altında, bilimsel bir ifadenin (herhangi bir ifade değil) veya bir hipotezin yanlışlanabilirlik (falsifiable) ölçütüne sahip olması gerektiği görüşü bulunmaktadır: yani, hipotezin yanlış olduğunu kanıtlayabilecek bazı ampirik testlerin gerçekleştirilebiliyor olması gerekmektedir.

Insan bilimleri içerisinde hangi kanıt, hipotezleri yanlışlayabilmek için yeterince güçlü bir kanıt olarak görülebilir?

Gözlemin ve deneyin bir kurama bağlılığı sorunu (Chalmers, 1982), neredeyse sonsuz biçimde daha karmaşık halde olan bağlam-bağımlı insan dünyası bir yana, fizik bilimlerinde bile saf yanlışlayıcı bakış açılarını sürdürmeyi zorlaştırmıştır. Popper'ın yaklaşımı, kuramları test etmek ve yanlışlayabilmek için deney ve gözlem yöntemlerini çekici hale getirir; ancak 'bir takım kuramlar, tüm gözlem ifadelerinden önce gelir' (Chalmers, 1982, s. 32). Yani, yanlışlamacılık - en azından saf bir tür olarak - doğası gereği döngüseldir: kuramı test etmek için gözlemlere başvurur, ancak kuram tüm gözlemlerden önce ve zımnen tüm gözlemlerde vardır.

İnsan bilimlerinde, doğa bilimlerindeki gibi (özellikle de fizik bilimleri) yanlışlanabilen, ancak daha önce yanlışlanmamış olan genellemeler yapmak mümkün mü? Bunun mümkün olduğundan gerçekten şüphe eder oldum: Alanımızda özgün yeni bilginin ortaya çıkarılmasına ilişkin gereğinden fazla standardın bulunması, bir görüşün nihai ve uzlaşmacı bir 'yanlışlamasının' neredeyse imkânsız olması anlamına gelmektedir. (Ya da davranışçılığın şu ana kadar gözden düşmüş olması olgusu bir yanlışlamayı mı ifade etmektedir? Muhtemelen hayır.)

Bilimin doğasıyla ilgili yanlışlamacı görüşlere yönelik önemli bir itiraz, Thomas Kuhn'a (1970) aittir. Kuhn, 'paradigma' fikrini kullanarak bilimsel devrimlerin tarihsel doğasını açıklamıştır. Ancak, Kuhn'un "paradigma" terimini kullanımı biraz kafa karıştırıcıdır: paradigma, bazen uygulamaya yönelik standartlar belirleyen özel bir bilimsel başarı örneği olarak, bazen de belirli bir alan için neyin kanıt olarak değerlendirilebileceğine yönelik kanunlar olarak kullanılır. Bu, David Stenhouse (1986) tarafından 'Kamu Gösterisi Paradigması' (Public Demonstration Paradigm-PDP) olarak karakterize edilen bir paradigma türüdür. Bununla birlikte, bir paradigmaya dair daha güçlü ve yaygın düşünce onun, hem mevcut gözlemleri açıklayan hem de ilginç sorular yöneltip, sonraki araştırmaları yönlendiren, karmaşık ve birbiriyle bağlantılı kuramlar ve fikirlerden oluşan bir yapı olduğu yönündedir. Stenhouse (1986), bu terimi bu kapsamda 'Ortak Varsayımlar Paradigması' (Common Assumptions Paradigm-CAP) olarak tanımlar.

Dolayısıyla, tek bir bilimsel 'gerçek', kendi başına bir varlık değildir, ancak paradigmayı oluşturan anlamların karmaşık ağı içindeki konumu üzerinden kendisine anlam ve gerçeklik atfedilmektedir. "Hidrojen kokusuz ve yanıcı bir gazdır" şeklindeki bir ifade, gazlar ve kokular olarak tanımlanan şeyler grubunu ve "yanıcı"nın ne anlama geldiğine ilişkin tanımı, yani 'bir ısı kaynağı tarafından ateşlendiğinde Dünya'nın atmosferindeki mevcut oksijen ile birleşerek ortaya enerjinin salındığını' önceden varsaymaktadır. Tabii ki, bu yanıcılık tanımı kendiliğinden, atmosfer, ISı ve ateşleme tanımlarını gerektirmektedir: ve neredeyse sonsuz biçimde buna benzer tanımları...

Kuhn, bilimsel devrimleri, "paradigma değişimleri" olarak tanımlamaktadır ki bu, mevcut zayıf paradigmaların daha güçlü ve yararlı olanlar tarafından ortadan kaldırılması demektir. Kuhn bunu etkileyici ve devrimci bir süreç olarak görmüş ve Kopernik devrimi gibi, bilim tarihinden benzer örneklere dikkat çekmiştir. Ancak böyle bir devrim gerçekleşmeden önce, baskın bir paradigmanın mevcut olması gerekmektedir. Kuhn, bu durumun geçerli olduğu zamanı "normal bilim" olarak tanımlamaktadır. Kuhn, tek bir baskın paradigmanın olmadığı, ancak birbiriyle çatışan çeşitli paradigmaların olduğu uğraş alanlarını 'bilimöncesi' (prescientific) olarak tanımlar ve böyle bir durumda bilimsel yazımın çok daha hantal hale geldiğini belirtir, çünkü temel kavramlara ilişkin, sorgulamadan kabul edilen ortak bir söz dağarcığı yoktur-her yeni bilim insanı, tartışmasının gerektirdiği her kavramı ilk ilkelerden kendisi türetmeli ve bu ilkeleri doğru kabul etmelidir. 
Imre Lakatos'un (1970), bakış açısı Kuhn'unkiyle kaydadeğer birçok açıdan farklılık gösterse de, "araştırma programları" Kuhn'un paradigmalarına oldukça benzerdir ve bir dereceye kadar mevcut tartışmalar açısından birlikte ele alınabilirler. Her ikisi de, (farklı şekillerde) daha iyi yapılar tarafından alt edilebilen, içsel olarak tutarlı kuramlardan oluşan karmaşık yapılardır. En önemli fark, Lakatos'un bilim tarihini devrimsel olmaktan çok evrimsel olarak görmesidir: kısa ve şiddetli bir devrimle eski paradigmanın tamamen devrilmesinden ziyade, araştırma programlarını benzer ortamlarda birlikte büyüyen, ancak daha fazla taraftar ve kaynak için birbirleriyle yarışan programlar olarak tanımlamaktadır. Bilim insanları ve araştırma fonları onları terk ettiği için güçlü bir şekilde rekabet edemeyen araştırma programları, bir anda gözden düşmeye başlar: bunlar, "yozlaşan programlar" olarak tanımlanmaktadır. Bu esnada, diğer araştırma programları dünyayı daha iyi açıklamaya ve daha yararlı olmaya başlamış gibidir. Kaynaklar bu programlara doğru akar ve bu programlar "ilerici" araştırma programları haline gelirler. Araştırmanın yürütüldüğü 'iklim'de bir değişiklik olmasıyla yozlaşan bir programın yeniden ilerici olması veya bunun tam tersi olarak nitelendirilmesi de mümkündür.

Bu bakış açılarından her birinin, çeşitli düzeylerdeki eğitimde araştırma uygulamaları açısından değeri vardır. "Paradigma savaşları" açısından (Gage, 1989, Paulston, 1990), Lakatos'un yozlaşan ve ilerici araştırma programları şemasının, Kuhn'un kuram değişimini tanımlayan devrimci yaklaşımından daha güçlü olduğuna inanıyorum. Açıkça görülmektedir ki, eğitimde hem nitel hem de nicel araştırma programları büyümekte ve gelişmektedir ve bağlılığın bunlardan birine ya da diğerine geçtiği tam bir 'bilimsel devrim' olacak gibi görünmemektedir- ve bence de olmamalıdır. Bunun yerine metodolojiler, belirli değerler setine ve epistemolojik bağlııklara dayanan belirli amaçlar için seçilir ve belirli bağlamlarda kullanıır.

Bilim felsefesindeki bu bakış açıları içindeki en güçlü kavram belki de Kuhn'un "bilim-öncesi topluluk" kavramıdır ki; tek bir kapsayıcı paradigmanın (Stenhouse'un [1986] CAP-Ortak Varsayımlar Paradigması- gibi) olmadığı, ancak birbiriyle rekabet eden bakış açılarının ve yaklaşımların olduğu durumları ifade etmektedir. Bunun, şu anda var olan durumuyla eğitim araştırması alanını çok iyi tanımladığını ve Kuhn'un bilimin böyle bir ortamda nasıl yürütüldüğüne ilişkin tanımının, eğitimde araştırmanın yürütülmesi için güçlü bir başvuru kaynağı olduğunu düşünmekteyim. Meslektaşlarımıza ve sorumluluk alanımızdaki kişilere yazılı raporlarında eğitim araştırmalarını sunarken başvurabilecekleri ve yazma görevini basitleştirecek bir Ortak Varsayımlar Paradigması (CAP) bulunmamaktadır. Yazı yazarken, hem çalışmanın gerçekleştirildiği ve gerekçelendirildiği varsayımları hem de niteliğinin değerlendirileceği uygun standartları açıkça belirtmek gerekmektedir.

Ama belki de eğitim araştırmalarında tek bir paradigma arayışı temelde hatalıdır? Ya da eğitim araştırmasına hizmet edecek, güçleri birbiri ile karşılaştırılamaz paradigmalar karışımını aramak da? Durumun şu şekilde olduğuna inanıyorum: eğitim araştırmalarında oluşturulan kuram, ana oyundan çok bir yan üründür. Tümevarım ve tümdengelim yoluyla kuram oluşturmak için bir model geliştirmek ve bunları uygulayıcıların kullanabilmesi için reçeteler sunmak, daha sonra (genellikle) uygulayıcıların bu uzaylı reçeteleri uygulamadaki 'başarısızlıkları' için dövünmek, öğretmenlere ve öğrencilere hizmet vermenin bir yolu olarak temelde hatalıdır.

\section{Teknoloji Felsefesinden Modeller}

Edward Constant (1973), teknolojiye Thomas Kuhn'un (1970) paradigmalar ve devrimler modelini uyguladı, ancak sadece Stenhouse (1986) tarafından ana hatları çizilen Ortak Varsayımlar Paradigması kavramını kullandı ve Kamu Gösterisi Paradigmaları (Public Demonstration Paradigms) ya da 'örnek vakalar'a yönelik bir ihtiyaca dikkat çekmedi. Gary Gutting (1980), PDP'lerin teknolojik değişimdeki rolünü dikkate alarak bu eksikliği giderdi. Ne var ki, bu bakış açılarından her ikisi de nihayetinde tatmin edici değildir, çünkü bunlar yeni 'zanaatların' (techné) geliştirilmesi için yeni bilginin (scientia) gelişimini ve yeni çalışma ve praksis biçimlerini açık bir şekilde tanımlamayı amaçlayan bir bakış açısını uyarlamaya çalışırlar. (Kuhn'un şeması, mecazi ya da analojik olarak yararlı olduğu birçok bağlamda benimsenmiştir, fakat belki de öğrenme kuramları (Geelan, 2000) ve eğitim araştırmaları (Geelan, 2001b) dahilinde doğrudan uygulanmamalıdır.

Blacker (1996), her biri geniş çapta pro- ve anti-teknoloji perspektifleri ile tamamlanan iki teknoloji felsefesi kutbunu birbirinden ayırmaktadır. 'Varlıkçı-Substantif (Substantivist)' bakış açıları, teknolojilerin toplumları şekillendirdiğini ve bireylerin ilişkilerini ve faaliyetlerini belirlediğini iddia eder. Heidegger, Habermas ve özellikle Jacques Ellul'un bakış açısı, genel olarak, varlıkçı-substantif (substantivist) görüşün anti-teknoloji ya da en azından eleştirel bakış açısına yatkındır. 'Araçsalcı' bakış açısı, teknolojiyi insani amaçlara ulaşmak için seçilen ya da ortaya konulan basit araçlar olarak değerlendirir ve bir noktaya kadar teknolojileri tarafsız olarak görür: bu amaçları tanımlayanlar insanlardır. Blacker'in işaret ettiği gibi bu bakış açısı, sezgisel bir güç içerir ancak çekiç, kalem veya bilgisayar gibi 'bireysel' araçlara daha iyi uygulanır. Teknolojinin doğası itibariyle 
kendisiyle kuracağımız etkileşimi belirlemeye yöneldiği, elektrik gücü şebekeleri veya internet gibi daha büyük ölçekli teknolojik sistemlere uygulanması daha zordur.

Paul Durbin (1998) teknoloji felsefesinin, belki de akademik meşruiyet ve ödül arayışılla yanlış yollarda gezdiği görüşündedir:

Bad Homburg'da, Alman meslektaşlarımız Hans Lenk ve Günter Ropohl'dan alıntıladım:

Çok disiplinli ve sistem-benzeri birbirinin içine geçerek kenetlenen tekn(oloji)k problemler ... sistem analistlerinin ve sistem planlayıcılarının ... sosyal bilim uzmanlarının ve belirli bir alanda uzmanlaşmamış olanların disiplinler arası işbirliğini gerektirir. Felsefe, disiplinler arası çabanın zorluğunu kabul etmek zorundadır. ... Kısıtlı ve katı akademik felsefenin fildişi kulesinden dışarı çıkılmalıdır (Durbin, 1983, s. 2).

Ancak bu öneriye harfi harfine uymalı ve sadece diğer uzmanlarla değil; aynı zamanda, ciddi çağdaş sosyal problemler için ilerici çözümler arayan tüm iyi niyetli vatandaşlarla işbirliği yapmalıyız. (Durbin, 1998)

Bu çağrı, bilim felsefesinin içinden Paul Feyerabend'in savunmasıyla bağlantılıdır:

\begin{abstract}
... benim kaygım ne akılılık, ne bilim, ne de özgürlüktür- bu gibi soyutlamaların faydasından daha fazla zararı vardır- benim asıl kaygım bireylerin yaşamlarının kalitesidir. Bu kalite anlayışı, değişiklik önerisi yapmadan önce kişisel olarak deneyimlenip öğrenmeyi gerektirmektedir. Başka bir deyişle: değişim önerileri, uzak 'düşünürler'den değil, arkadaşlardan gelmelidir. Daha önce hiç görmediğimiz insanların yaşamları hakkında muhakeme yapmayı durdurmanın zamanıdır; insanlığın ... iyice ısıtılmış ofislerde boş boş çene çalan insan grupları tarafından kurtarılabileceği inancından vazgeçme zamanıdır. Mütevazi olma ve eğitim ihtiyacı duyan kara cahil biri gibi, düşüncelerinden yararlanılacak kişilere yaklaşma zamanıdır. (Feyerabend, 1987, s. 17)
\end{abstract}

Bu yükümlenme, Güney Amerika'daki Paulo Friere'nin (1970, 1982) ve Orlando Fals Borda'nın (1979) 'derinlemesine' eylem araştırması yaklaşımlarına benzemekte ve Dick Corbett ve Bruce Wilson'ın (1995) araştırmacıların 'öğrenciler için değil öğrencilerle birlikte farklılık yarattığına' ilişkin görüşünü anımsatmaktadır.

Aşağıdaki bölümler, bu tür yerel, yerleşmiş, alçakgönüllü, katılımcı bir yaklaşımın eğitim alanındaki araştırmalara uygulanması fikrinden ortaya çıkan bazı konu ve özelliklerin araştırılmasını içermektedir.

Teknolojik Problem Çözme ve Çözümlerin Yerel Karakteri

Fizik bilimlerindeki modellerin özelliklerinden biri, genelleme arayışlarıdır: bir kuramın uygulama alanı ne kadar genelse, bu kuramın o kadar iyi olduğu yargısına varılır. Bu durumun, bu modellerin eğitim araştırmalarındaki belki de tek ve en kötü etkisi olduğuna inanmaktayım: herkese, her yere uyan bir kuram arayışı, kuramların insanların yaşama dünyalarına uygun düşmeyen tanımlamalarını görmezden gelen bir Procrustean $^{3}$ pratiği benimseme ya da daha kötüsü, bu tür konuları öğretmenler ya da öğrencilerdeki 'eksiklikler' olarak görme. Eğer 'bağlam', yukarıda tartışılan sınıfın tüm iç ve dış boyutlarını içerdiği kadar zengin olarak anlaşılıyorsa, o zaman tek bir bağlamda geliştirilen bir çözümün, farklı bir bağlamda uyarlanmadan uygulanabilmesi sezgisel olarak mümkün görünmemektedir. Teknolojik problem çözme bakış açısından, bir bağlamda belirli bir problemin çözümü, yeni bir bağlama doğrudan uygulama yönünde bir reçete değil; fakat yaratıcı ve yansıtıcı bir şekilde test edilmesi ve optimal olan yeni bir çözüm oluşturmak için yeni bir bağlamda denenmesi gereken sürekli olarak artan beceriler ve olası çözümler kümesinin ortaya konulmasıdır.

Aşağıda açıklanan 'eğitim alanında uzman kişi (connoisseur) ve eleştirmen' rolü, esasen bir yerde gerçekleştirilen çözümlerin "savaş hikayeleri"ni, başka bir yerde eğitimcilerle paylaşmanın rolüdür. Bu durum her bir eğitimcinin kendi bağlamında "tekerleği yeniden icat etmesi" gibi bir deneyim süreci olmasındansa, uygulama topluluğunun kendi içinde bir deneyim birikiminin olmasını sağlamaktadır. Bu betimlemedeki "Tekerleği yeniden icat etme" metaforu, yerinde bir ifadedir. Tekerleğin başka bir yerde icat edildiğini bilmek,

\footnotetext{
${ }^{3}$ ÇN: Yunan mitolojisinde Procrustes, kendisine konuk olan yolcuların boylarını yatağa uydurmak için kol ve bacaklarını çekip uzatan, ya da kırıp kısaltan sadist ruhlu dev. Kaynak: https://tr.wikipedia.org/wiki/Procrustes
} 
bir tekerleğin yeni bir bağlamda başarıyla kullanılmasını sağlamak için yeterli değildir. Örneğin, şunlara karar vermek gerekecektir:

- Basit bir silindirin mevcut sorunu çözmek için yeterli olup olmadığı veya bir tekerleğin daha iyi çalışıp çalışmayacağı;

- Tekerleğin içi dolu, bütün halde bir janttan mı olacağı, ya da bunun yerine jant tellerinin yeterli olup olamayacağı;

- Bir lastiğin gerekli olup olmadığı;

- Hangi malzemelerin elimizde mevcut olduğu ve de maliyet ve güvenilirliğin optimal dengesini neyin sağladığı;

- Bu uygulamada mukavemetin mi yoksa düşük sürtünmenin mi daha yüksek öncelikte olduğu.

$\mathrm{Bu}$, örnek sorunların çok da kapsamlı olmayan bir listesidir ve elbette, bu sorunların her biri, diğerlerini etkileyecektir: tekerleğin içi dolu, bütün halde bir janttan oluşması beraberinde ağırlık dezavantajını getirmektedir; jant teli takılıp takılmayacağı, eldeki mevcut materyallerin ve teknolojilerin türüne bağlıdır; ve hemen hemen tüm bu sorunların çözümündeki amaç, geniş bir bağlam yelpazesine genellenebilirlikten ziyade, belirli bir bağlam ve belirli bir amaç için optimal olan bir çözümün bulunmasıdır.

\section{Eğitim Araştırmalarının Yeni Doğası}

Jack Whitehead'in 1989 tarihli çalışmasında belirttiği bakış açısı, eğitim araştırmaları konusundaki düşüncelerim üzerinde çok etkili olmuştur; ancak şimdi kendisinin bu konuda yeterince derine inmediğini düşünmekteyim. Jack, eğitim alanında 'yaşayan eğitim kuramının' gelişsimi olarak tanımladığı bir inceleme/araştırma yaklaşımı izlemektedir (Laidlaw ve Whitehead, 1995; Whitehead, 1989).

Whitehead, uygulama içindeki eğitimcilerin; psikoloji, sosyoloji, antropoloji, felsefe disiplinlerinin ve hatta kurumsal düzeydeki eğitim araştırmalarının ortaya koyduğu kuram ve formal araştırmalardan çok, 'uygulamamı nasıl geliştiririm?' türünden sorularla, doğrudan kendi uygulamalarına dair eğitimsel ve kişisel değerlerini yansıtan bir kuramsal anlayış geliştirmeye çalıştıklarını öne sürmektedir. Kendi bakış açım gibi, Whitehead'inki de açıkça değer yüklüdür: öğretmenler belirli şeylere değer verir ve öğretimi geliştirmeye yönelik çabalar, kaçınılmaz olarak değer verdiğimiz şeyleri daha eksiksiz bir şekilde uygulamalarımıza yansıtmamıza yönelik bir gayret sürecidir.

Whitehead, hem dışsal/kurumsal hem de içsel/biyografik çeşitli kısıtlamalardan dolayı, hiçbirimizin benimsediğimiz değerleri ve inançları pratikte tam anlamıyla uygulamalarımıza dahil edemediğimizi ifade etmektedir. Şöyle yazmaktadır:

Eğitim kuramının doğası hakkındaki anlayışım, izlediğim, sınıf uygulamalarımı yansıtan video çekimlerinden etkilenmiştir. Gördüm ki; "Buradaki eğitim sürecini nasıl iyileştiririm?" sorusu içindeki 'Ben' de, yaşayan bir çelişki vardı. Yani 'Ben' ifadesi, birbirini dışlayan iki zıtlık içeriyordu; sahip olduğum eğitim değerlerine uyan deneyimlerim ve bunların karşıtları... Bizleri, içinde bulunduğumuz durumu geliştirmeye yönelik alternatif yollar aramaya yönelten şey, tam da bu çelişkiden doğan gerginlik değil midir? Bu tür karşıtıkları, eğitim uygulamalarımızı tanımaya dönük sunumlarımızda kaynaştırarak, bireylerin eğitimsel gelişimi için tanımlar ve açıklamalar yapabiliriz. (Whitehead, 1989)

Elbette benim deneyimim ve emin olmamakla birlikte tüm öğretmen arkadaşlarımın da deneyimi bu şekilde oldu. Havari Paul şöyle demektedir:

Ne yaptığımı anlamıyorum. İstediğimi yapmıyorum ama nefret ettiğim her şeyi yapıyorum... Doğru olanı yapabilirim ama yapamıyorum. İyi olan şeyi yapmak istiyorum ama yapmıyorum. İstemediğimi yapıyorsam, bunu yapan artık ben değil, içimdeki şeytandır (Romalılar 7: 15, 19. RSV).

Gençlerle etkileşimde bulunma ve onlara öğretmeye dair, kişisel ve eğitsel değerlerimiz üzerine temellenen bazı amaçlarımız vardır, fakat kendi uygulamamızda kendimizi bu değerleri ve amaçları reddeder halde buluyoruz. Whitehead (1989), bu çelişkilere ilişkin sorgulamalarımızı doğrusal, önermesel-mantıksal bir sunumla saklamak yerine, onları diyalektik bir biçimde sunmak için gayret etmemizi önermektedir. Bir yanda 
değerlerimiz ve amaçlarımız diğer yanda ise uygulamamızın algılanan eksiklikleri arasındaki gerginlik, dikkatli sorgulamalar yoluyla uygulamamızı geliştirmeye yönelik girişimlerimizi yönlendiren bir dinamodur.

Ancak yine de Jack Whitehead'in yaklaşımı, yeni bilginin (sınıf yaşantılarına yönelik) dışsal yargı ve onaylanmaya tabi olarak ortaya konulmasıyla ilgilidir. Sınıf yaşamının fazlasıyla belirsizlik ve karmaşıklık içerdiğini ve yazılı araştırma raporlarındaki anlayışlarımızın geçici niteliğini ileri sürerken, kesin görünene karşıt olarak, kuramın mantıksal önermelerinde olduğu gibi, eğitim araştırmalarının katıksız bir ürünü olarak tekstlerin yaratılmasını önermenin çok uzağına gitmez. En azından öğretmen ve öğrenciler dışındaki kitlelere sunulan tekstler, bazı açılardan gelişimsel amaçlara uygunsuz görünmektedir; hatta eğitimsel yararı anlaşılamamaktadır. Whitehead (Laidlaw \& Whitehead, 1995), bazı açılardan, kendisinin ve öğrencilerinin ürettiği bilginin akademideki meşruiyeti konusunda, akademisyenler ve diğer dışsal kapı bekçileri ile mücadele etmek durumunda kalmıştır. Bu kavga, akademisyenler için, aşağıda ana hatları verilen araştırma rollerini değerlendirmede bir değere sahip olsa da, öğrencilerin çıkarlarına hizmet etme açısından verimsiz bir enerji yönetimi gibi görünmektedir.

\section{Uygulayıcıların Rolï}

Eğer eğitim araştırmalarının amacını genellenebilir geniş ölçekli kuramlar geliştirme yeni bilgiler ortaya koyma arayışı olarak görmekten kaçınırsak, bunun yerine 'sınıfımdaki yaşantıları nasıl iyileştirebilirim' türünden soruları yanıtlamak için teknolojik problem çözme yaklaşımını takip edersek, uygulayıcıların eğitim araştırmalarındaki rolü, şimdi olduğundan çok daha merkezi ve temel bir konuma gelecektir. Yaygın bir kavram yanılgısı olan bilim ve teknoloji modeli (bilim insanları temel araştırmaları yaparlar, teknoloji uzmanları da bunu uygular), eğitimde çok yaygın uygulanan bir modeldir: akademisyenler temel araştırmalar yaparlar, öğretmenler de bunu uygular (ya da daha doğru bir ifadeyle, öğretmenler uygulamada 'başarısız' olurlar ve akademisyenler de şikâyet eder!). Eğer asıl amaç, öğrencilere daha iyi yollarla eğitim hizmeti vermekse, o zaman farklı araştırma biçimleri daha değerli olacaktır.

Donald Polkinghorne (1992), psikolojideki akademik araştırmalarla 'pratiğin postmodern epistemolojisi' olarak tanımladığı şey arasındaki ayrımı şöyle tartışı:

Psikolojideki uygulamalar, yeni pragmatizm için bir örnektir. İnsan ruh dünyasının parçalanmış ve bambaşka olduğu ve bu dünyaya dair bilgilerin kesin bir dayanağı olmayan insan yapılandırmaları olduğu anlaşılmaya başlanmıştır. Ancak bu bilgi, kötümser bir kuşkuculukla geri çekilmekten çok, stres altındaki insanlara yardımcı olacak farklı yaklaşımlara açık olmayı getirmiştir. Psikoloji uygulamaları bilgi alanı, uzman toplulukların danışanlara yarar sağlamış deneyimlerinin toplamından oluşur. İleri sürülen bir bilginin kabul edilebilirlik ölçütü, uygulamadaki verimliliğidir. (Dolayısıyla) uygulama epistemolojisinin eleştirel terminolojisi, doğruluk metaforlarından yarar metaforuna doğru yön değiştirmiştir (Polkinghorne, 1992: 162).

Bakış açısındaki bu değişim, bu çalışmada savunduğum değişimin tam kalbinde yatmakta. Bilginin üretimi ve meşruiyet kazanmasına dair metaforlar yerine, sınıfta olan biteni daha iyi hale getirmeye dönük bir eğitim hizmeti verilmeye, 'uzmanlık alanının bilgi tabanı, alan uzmanlarının [öğrenciler için] yararlı buldukları deneyimler toplamından oluşturulmaya' çalışılırsa; eğitim araştırmalarının uzmanlık alanına ilişkin bilgi tabanı oluşur ve böylece bu bilgilerin bir standardı karşılayıp karşılamadığı yargısına varılırken, aynı zamanda bu bilgilerin hem 'gerçekte karşılığı olan ve doğru (geçerli ve güvenilir) bilgiler mi' olduğu, hem de 'işe yarar, işler bilgiler mi' olduğu sorularına cevap aranmış olur. Tabii ki, bu basit bir soru değildir! Bu soru aynı zamanda 'kimin için çalışılmakta?' ve 'hangi amaçlar için işe yaramaktadır' şeklindeki soruları peşi sıra getirir. Seçilen eğitsel amaç ve araçları sorgulayan özgürleştirici ilgi (interest) (Habermas, 1971) uzman topluluğu içinde gerçekleşen tartışmaların önemli bir parçası olmaya devam etmektedir. Araştırmalardaki bu 'deneyimin toplamı' bakış açııının, konu ile ilgili işe yararlık ölçütüyle birlikte, bilimden ziyade yeni teknolojilerin geliştirilmesinde kullanılan yaklaşıma benzer olduğunu ifade etmek isterim. Yeni teknolojiler açısından, gerçekten de 'kimin için çalışılmaktadır' sorusu piyasalarda (marketplace) yanıtlanmaktadır: 'Bu aracı kim satın alacak'. Solcu ruhum, eğitimin 'pazarlanması' fikri ile eğilip büzülmektedir: eğitimde 'neyin işe yaradığı' ifadesini okulun pazarlanmasında ve ebeveynlerin seçimlerinde ölçüt haline getirme düşüncesi. (Bu, eğitimdeki ücretli programların ideolojik temelini oluşturur ve bir çeşit yeni muhafazakar reformdur.) Teknolojik ürünlerin pazarlanmasındaki başarı ki, gerçekten işe yaradıkları kuşkuludur ama iyi pazarlanmışlardır, bu yönde bir uyarıcı not olabilir ve ben inanıyorum ki, temelde profesyonel topluluk, 
eğitimde iyi olan, açıkça savunulabilir, kavramına, sadece "popüler veya moda" olan üzerine temellenen piyasa okullarından daha çok sahip çıkar. Eğer kamusal eğitim devam edecekse, eğitimcilerin, eğitimde neyin değeri olduğuna ilişkin görüşlerini kamuoyuna daha iyi pazarlama konusunda şu an yaptıklarından daha iyi bir iş çıkarmaya ihtiyaçları olacaktır. Neyin işe yaradığı ve kimin için işe yaradığı gibi sorular, geniş bir uzlaşıyla belirlenmiş, olmasını istediğimiz toplum üzerinde referans alınarak cevaplanmalıdır.

Teknolojik problem çözme üzerine modellenen bir eğitim araştırması ortamında, uygulayıcıların günü gününe ve dakika dakika yaptığı deneyler araştırmayı oluşturur; o, 'savaş hikayeleri' içinde yaşantıların paylaşılmasıdır, yeni bir öğretmenin çıraklık deneyimleri aracılığıyla gelişimidir, (böylece) bilginin büyümesi ve üretilen bilginin test edilmesi sağlanır. Bu durumun, öğretmenlerin başlangıçta nasıl eğitildiklerine ve devam eden mesleki gelişimine dair doğurguları olacaktır: diğer öğretmenlerin çalışmalarını gözlemlemek için ayrılan zaman, öğretimin tartışılacağı ve "savaş hikayeleri" ile deneyimlerin paylaşılacağı bir ortam hayati öneme sahiptir. Öğretmen eğitimi, sınıflarda diğer uzmanların katılımı ile artııımış fırsatlar sunan, daha çok çıraklık benzeri bir model olabilir.

\section{Akademisyenlerin Rolü}

Bu konferansa katılan çoğu katılımcı için (eğitimde akademisyenler için) bir rol kaldı mı? Eğer uygulayıcılar sınıflarda araştırma faaliyetlerinin merkezinde yer alırsa ve benzer şekilde, okullardaki ve bölgelerdeki yöneticiler politikaya dönük araştırmaları yürütürse ve eğer araştırma tekstlerinin üretimi eğitim araştırmalarının esas iş alanının kıyısında kalıyorsa, geriye bizim için yapacak ne kalmaktadır?

Elliott Eisner'in (1998), araştırmacıları eğitimsel uygulamaların uzmanları ve eleştirmenleri olarak tasavvur etmesi beni olası bir çıkış yoluna götürmektedir. Eisner, eğitim uzmanlığını (connoisseurship) şarap uzmanlığıyla karşılaştııır ve hem 'kendi içinde' deneyiminin niteliğine değer biçme, hem de incelikle işlenmiş büyük resim içinde kendini konumlandırma konusundaki yeteneğin önemine dikkat çeker. Yani, bir eğitim uzmanı, yukarıda açıklanan boyutların birçoğunu kullanarak, sınıfta yaşanılan belirli bir olayı ya da üzerinde durulan durumu hem olayın kendisi olarak hem de daha büyük bir olayın temsili olarak deneyimleyecektir.

Tek başına uzmanlık, uzmanın memnuniyeti için yeterlidir; ancak bu, deneyimi paylaşma ya da benzer şekilde deneyimlenmiş nitelikler konusunda diğerlerini eğitmede fayda sağlamaz. Eisner, uzmanlık deneyimlerinin başkalarına yeniden sunulması sürecini, kitapların, filmlerin ve sanatın eleştirilmesine benzeterek, "eğitimsel eleştiri" olarak tanımlamaktadır. Eisner'e göre, eleştirmen, okuyucunun dikkatini deneyimin niteliğine çekebilen kişidir, böylece okuyucu, bir düzeye kadar bizatihi deneyimde kendine yer bulabilecek ve aynı zamanda, kendi deneyimiyle bağlantı kurma ve anlama yönünde daha yeni fırsatlar için eğitilmiş olacaktır.

Dolayısıyla, akademisyenin rolü film ya da müzik eleştirmenininkine benzer hale gelir: daha geniş bir bağlam içine alarak ve bunları okuyucular için erişilebilir hale getirerek uygulayıcıların çalışmaları için bir "değer alanı" oluşturmak. Rolün kendisi açıkça eğitimseldir ve eğer iyi bir şekilde gerçekleştirilirse, okurların eleştirel güçlerinin ve hayata dair bilgilerinin gelişmesini sağlayabilir.

İlintili bir diğer konu medyanın rolüdür. 'Müzik hakkında yazmak, mimarlık hakkında dans etmek gibidir' şeklinde bir ifade vardır ve belki de benzer bir ifade öğretim hakkında yazma konusunda da söylenebilirdi. Belki de tekst, öğretimle ilgili neyin iyi olduğunu göstermek ve tartışmak için en iyi ya da en uygun araç değildir (ya da eğer tekst iyi bir araç ise -aslında Evan Hunter'ın 'The Blackboard Jungle' adlı romanı gibi romanlar, tekstin gerçekten de çok iyi bir araç olabileceğini öne sürmektedir- belki de bu üstünlügünü hak etmemektedir ve bunun yerine ses, video ve yeni medya içeren temsili araç setinin bir parçası haline gelmelidir). Öğretimin açıklayıcı notlarla videoya çekilmesi eğitimsel 'performansların' eleştirilmesinde ve tartışılmasında halihazırda zaten kullanılmaktadır ve araştırmalarda diğer medya araçlarının kullanması olanağı önümüzdeki birkaç yıl içinde önemli ölçüde artacaktır. Bu araçların yukarıda tartışıldığı gibi 'içerdeki' uygulayıcıya yönelik araştırmalarda kullanılması, medyanın eğitim alanındaki akademisyenlerin uzmanlıklarına ve eleştiri işlevlerine yönelik kullanılmasıyla hem benzerlik hem de farklılık oluşturacaktır.

\section{SONUÇ}


Bu çalışmada, eğitim araştırmalarının amacını kuram oluşturmak olarak görmekten kaçınmamız gerektiği görüşünü ileri sürdüm. Eğitim araştırmaları, eğitim uygulamalarına fayda sağlamayı amaçladığı ölçüde (araştırmacıların ve akademisyenlerin kişisel ilgilerindense), her türdeki genelleme arayışından kaçınıp; pratik, somut, zengin, karmaşık ve her şeyden önce sınıfta öğretmenlerin ve öğrencilerin ihtiyaçlarına neyin hizmet edeceğine yönelik bağlama-duyarlı anlayışlar aradığı zaman (eğitim alanındaki araştırmalar) daha güçlüdür.

Bu bakış açısı, bilimsel/kuramsal eğitim araştırmaları idealinden düş kırıklığı içinde bir "vazgeçiş" değil; daha ziyade çok geç kalınmış bir tanıma olarak görülmelidir, (zira durum) bir cehennem kardeşliği gibiydi. Bilimsel yöntemleri sınıfta uygulama çalışmaları, katılımcıların ihtiyaçlarından yola çıkmaktansa, 'bilimsel' araştırmalara yansıyan bir meşruiyet arayışına dayanıyordu. Eğitim araştırmalarını, 'Tam da burada, şimdi içinde bulunduğum yerde eğitimi nasıl geliştirebilirim?" türü soruları ele almaya yönlendirmek; bu soruları, amaç ve uygulamanın diyalektiği içinde çeşitli yollarla ele almak, öğrenmeyi geliştirici uyarlamalara yönlendirmek demektir.

Elbette geriye, bu tür bir dersin hem önerilebilirliği sorusu hem de uygulanmasına yönelik pratik detayları hakkındaki sorular kalmaktadır. Bu kısmı devamı gelecek bir tartışma için başlangıç noktası olarak bırakacağım.

\section{KAYNAKÇA/REFERENCES}

Biggiero, L. (2001). Sources of complexity in human systems. Nonlinear Dynamics, Psychology, and Life Sciences 5(1): 3-19.

Blacker, D. (1996). Philosophy of technology and education: An invitation to inquiry. Philosophy of Education Society Yearbook. http://www.ed.uiuc.edu/EPS/PES-yearbook/94_docs/BLACKER.HTM

Chalmers, A.F. (1982). What is this Thing Called Science?(2nd ed.). St Lucia, Qld: University of Queensland Press.

Constant, E.W. (1973). A model for technological change. Technology and Culture, (14), 554.

Denzin, N.K. \& Lincoln, Y.S. (1994). Handbook of qualitative research. Thousand Oaks, CA: Sage.

Denzin, N.K. \& Lincoln, Y.S. (2000). Handbook of qualitative research. (2 ${ }^{\text {nd }}$ Ed.) Thousand Oaks, CA: Sage.

Durbin, P.T. (1998). Advances in philosophy of technology? Comparative perspectives Techné: Journal of the Society for Philosophy and Technology, 4(1), 4-15.

Eisner, E.W. (1998). The enlightened eye: Qualitative inquiry and the enhancement of educational practice. Upper Saddle River, N.J.: Merrill.

Fals Borda, O. (1979). Investigating reality in order to transfom it: The Colombian experience. In Stephen Kemmis \& Robin McTaggart, eds., The Action Research Reader. Deakin University, Geelong.

Feenberg, A. (2000). From essentialism to constructivism: Philosophy of technology at the crossroads. In E. Higgs, D.Strong, and A. Light, (Eds.), Technology and the Good Life. Chicago: University of Chicago Press. [Online: http://www-rohan.sdsu.edu/faculty/feenberg/talk4.html]

Feyerabend, P.K. (1987). Farewell to Reason. Verso, London.

Gage, N.L. (1989) The paradigm wars and their aftermath: a "historical" sketch of research on teaching since 1989. Educational Researcher 18(7): 4-10. 
Geelan, D.R. (2001a). The empty centre: Power/knowledge, relationships and the myth of 'student centred teaching' in teacher education. Australian Journal of Teacher Education, 26(2): 27-37.

Geelan, D.R. (2001b). Feyerabend revisited: Epistemological anarchy and disciplined eclecticism in educational research. Australian Educational Researcher, 28 (1): 129-146.

Geelan, D.R. (2000). Sketching some postmodern alternatives: Beyond paradigms and research programs as referents for science education. Electronic Journal of Science Education, 5(1).

https://wolfweb.unr.edu/homepage/crowther/ejse/geelan.html

Gutting, G. (1980). Paradigms and Revolutions: Appraisals and Applications of Thomas Kuhn's Philosophy of Science, Notre Dame: University of Notre Dame Press.

Habermas, J. (1971). Knowledge and Human Interests. Translated by J.J. Shapiro. Boston: Beacon Press.

Kuhn, Thomas S. (1970). The Structure of Scientific Revolutions. University of Chicago Press, Chicago.

Lakatos, I. (1970). 'Falsifications and the methodology of scientific research programs', in Imre Lakatos \& Alan Musgrave (Eds.), Criticism and the Growth of Knowledge. Cambridge University Press, Cambridge.

Laidlaw, M. \& Whitehead, J. (1995, April). An educational epistemology of practice. Paper presented in the Self-Study of Teacher Education Practices Special Interest Group, AERA, San Francisco.

Mezirow, J. (1981). A critical theory of adult learning and education. Adult Education, 32(1): 3-24.

Paulston, R.G. (1990). From paradigm wars to disputatious community. Comparative Education Review 34(3): 395-400.

Polkinghorne, D.E. (1992). Postmodern epistemology of practice. In Steinar Kvale (Ed.), Psychology and Postmodernism. London: Sage.

Popper, K.R. (1968). The Logic of Scientific Discovery. Hutchinson, London.

Popper, K.R. (1965). Conjectures and Refutations: The Growth of Scientific Knowledge (2nd ed.). Basic Books, New York.

Shulman, L.S. (1986). Paradigms and research programs in the study of teaching: A contemporary perspective. In M.C. Wittrock (Ed.), Handbook of research on teaching (3rd ed.) (pp. 3-36). New York: Macmillan.

Stenhouse, D. (1986). Conceptual change in science education: paradigms and language games, Science Education 70(4): 413-425.

Whitehead, A.J. (1989). Creating a living educational theory from questions of the kind, 'How do I improve my practice?' Cambridge Journal of Education, 19(1): 41-52.

İletișim/Correspondence

Prof. Dr. Mukaddes ERDEM erdemm@hacettepe edu.tr

Doç. Dr. Tuğba Öztürk tozturk@ankara.edu.tr 